\title{
Implementation of Six Sigma in Academia
}

\author{
Shashi Kiran G', Antara Sarode ${ }^{2}$, Sohan Chandrakanth ${ }^{3}$ \\ Assistant Professor, Department of Mechanical Engineering ${ }^{1,2}$ \\ Student, Department of Mechanical Engineering ${ }^{3}$ \\ Presidency University, Itgalpura Rajanakunte, Yelahanka, Bengaluru, Karnataka 560064. \\ ${ }^{\# 1}$ shashikiran@presidencyuniversity, +91-8197809897. \\ \#2antarasarode@presidencyuniversity.in, +91-8698487390. \\ \#3sohanchandrakanth@gmail.com,+91-8904155390.
}

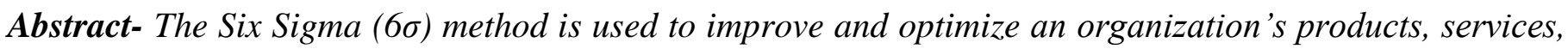
and processes by constantly decreasing defects. In this paper we try implementing the $6 \sigma$ methodology in Academia. The challenges and actuality of implementation of $6 \sigma$ methodologies successfully in Academia are immense. However, the benefits of applying $6 \sigma$ are equally great. The objective of this paper is to understand the evolution, benefits, and challenges of $6 \sigma$ practices in academia through a case study of Presidency University situated in Bangalore, Karnataka, India. The problem statement in the paper is the poor performance of students in academics and by using the DMAIC approach of $6 \sigma$ we try to identify and understand the causes and set out to improve them so the students can have better placement and academic opportunities. This paper is also an attempt to show the readers about the wide application of $6 \sigma$ in fields other than manufacturing and how it can be beneficial.

Keywords: Six sigma (6б), DMAIC, Academia, Presidency University, defects.

\section{Introduction}

The $6 \sigma$ concept was given to us by Motorola back in the 1980 s as a tool to improve/optimize products and maintain quality. The core of $6 \sigma$ is all about the continuous improvement of processes using the DMAIC (Define, Measure, Analyze, Improve, and Control) methodology or the DMADV (Define, Measure, Analyze, Design, and Verify) methodology. It has since then been widely adopted by many companies in various business sectors like Manufacturing, IT, Management sectors, etc. We often implement DMAIC approach for projects aimed at improving an existing business process at the company and the DMADV for projects aimed at creating new products or design processes from scratch. Fundamentally the $6 \sigma$ can be applied to any sector even though its application is widely seen in the manufacturing industry.

\section{Six Sigma in Education Industry}

If we think of it, $6 \sigma$ methodologies and Education sector seem to be a mismatch as education sector lacks the standard practices and inputs other business sectors provided to implement $6 \sigma$ methodology such as; production equipment, tangible and quantifiable inputs \& outputs and inventory. But, the education sector is known to have variables like unpredictable human factors which often don't work well to the statistics-based and controlled methodology such as $6 \sigma$. 
However, few areas of education can respond positively to $6 \sigma$ methodology. Those areas better suited for the application of $6 \sigma$ in the education sector are:

\section{i. Administration,}

\section{ii. Admissions / Enrollments,}

\section{iii. Academics and student performance.}

\section{Literature Review}

In the study "Applying Six Sigma in Higher Education Quality Improvement" by Dr. Quamrul H. Mazumder ${ }^{[1]}$, the impact on the quality of education see seen using $6 \sigma$ tools such as SPC, FMEA, , Lean, etc. SPC is used as the primary tools in the academia because of a huge quantity of information such as; student enrollment trends, graduation rate, CGPA rate, retention rates, etc. The DMAIC methodology is adapted in this study and it successful in improving the quality of students and the management functions. In the study, $3 \sigma$ was the initial $\sigma$ level. After identification of the problems, a solution was developed using DMAIC and solutions were presented in this paper. This resulted in higher quality and sustainable processes in the institution with higher levels of student satisfaction and success rates such as graduation and retention rates.

On the similar lines in "Lean Six Sigma Model To Improve Student Performance" by Tannu Vats and Sujata $^{[2]}$, gives us a clear understanding of tools of six sigma that can be implemented to improve the performance of students by the DMAIC methodology. Wherein the "Define" phase, the stakeholders (student, teacher, and others) can identify that there are problems faced during the student performance evaluation. for which later measure and analysis was performed using tools such as SIPOC, Survey Questionnaire for Student, Graphisims, and MATLAB tools were used. The Graph obtained from MATLAB showed the results of the score given by the stakeholders. Line and bar graph is used as Pareto chart which helped to identify that which of the $20 \%$ part of the overall system is producing $80 \%$ of error. The area where improvement is needed will be identified by the graph that is implemented using the score given by the different stakeholder's i.e. students, teachers, and other students. The test score is analyzed by using the formula that is drawn from the MATLAB tool and this it was concluded that the existing system requires more attention, rework, and improvement.

In the study "Utilizing Six Sigma for Improving Pass Percentage of Students" ${ }^{[3]}$ by Prabhakar Kaushik and Dinesh Khanduja. DMAIC was applied on the results at Shri Krishan Institute of Engineering and Technology. After analysis of the data collected, it was stated that the avg.passing rate of students at SKIET was $51.27 \%$ and had a $2.17 \sigma$ level. After implementation of six sigma, by analyzing the next five-semester results of the SKIET, the $\sigma$ level was found at 4.17 and the avg.passing rate increased to $61.35 \%$. 
And after reviewing, "Lean Six Sigma Implementation in Engineering Institutions", ${ }^{[4]}$ by C.R.S. Kumar, the author talks about lean six sigma for academic excellence and lists' out several Critical to Quality (CTQs) parameters, such as Student Success rate in examinations, Graduating percentage of students, Percentage of students with distinction, Percentage of Syllabus completed, etc. and also talks about the faculty members playing a vital role. From the perspective of teachers and instructors, Lean Six Sigma can be applied as follows:

i. Activities: Administration, Teaching

ii. Teaching: Syllabus, Instructions, Evaluation, Assigments, Question Papers, Feedback

iii. Research: Research Methodology, Publications, Patents, Graduating Mtech students and PhD.

iv. Administration: Faculty co-operation, Communication, etc

v. Organization: Workshops, Seminars, Conferences, etc.

And in "Impacts of Lean Six Sigma on improving a higher education system: a case study", ${ }^{[5]}$ given by Milad Haerizadeh and Vijaya Sunder M, was conducted at Allameh Tabatabai University in Tehran, Iran that was experiencing a high level of student complaints related to student services and advising. And six sigma tools were applied with survey approach in the measure phase similar to us here and Based on these findings the LSS team formed a focus group of students to explore more deeply the low satisfaction ratings. The findings from the focus group indicated and To improve the student service processes the LSS team implemented several improvements based on the data and focus group results such as, a faculty adviser was added as another resource for students for each major to provide perspective on technical aspects and job prospects; advising hours were extended into the afternoon until 5.15 p.m. on Saturday through Wednesday; an online database system was created to store student records electronically. This allowed all advisers to have immediate access to students' real-time files from any computer. It also reduced filing time and note taking to improve efficiency and much more. 


\section{Six Sigma Methodology}

Six Sigma has two methodologies. As mentioned before the DMAIC method or approach for projects aimed at improving an existing business process at the company and the DMADV method used for projects aimed at creating new products or design processes from scratch. In the Educational industry, processes cannot be created from scratch as established institutions have rules to follow which once in place can be only amended to a certain degree in which case DMAIC methodology is chosen.

\begin{tabular}{|c|l|}
\hline Define & Development of SIPOC process map. \\
\hline Measure & $\begin{array}{l}\text { To find out the factors affecting the process and student performance using sigma calculation and establishing a } \\
\text { data measurement system. }\end{array}$ \\
\hline Analysis & Development of Cause \& Effect (Fishbone) diagram and plotting Control charts using Minitab software. \\
\hline Improve & $\begin{array}{l}\text { The causes for failure or poor quality are be identified with a solution using FMEA and drafting an } \\
\text { implementation plan. }\end{array}$ \\
\hline Control & $\begin{array}{l}\text { The results of the new standardization or procedures are controlled over time and further improved using } \\
\text { different six sigma tools. }\end{array}$ \\
\hline
\end{tabular}

Table 1. DMAIC Methodology for Educational Process

\subsection{Case Study}

For this project, we are considering Presidency University, situated at Itgalpura, Rajanakunte, Yelahanka, Bengaluru, Karnataka, India - 560064. It is a private university that was established in 2013 in Yelahanka, Bangalore by the Presidency Group of Institutions (PGI). Presently, the University offers UG, PG, and Ph.D. programs in various streams, such as Engineering, Commerce, Management, Law, Design, Science, Computer Application, and more. The University has more than about 400 permanent faculty members across all departments. It comprises six constituent schools, which are School of Engineering, Management, Law, Design, Commerce, and Information Science.

For our study, we are focusing on School of Engineering having a total of 3000+ students' strength across various departments (Computer Science, Civil, Mechanical, Electronics and Communications Engineering, Electrical and Electronics Engineering, Petroleum Engineering) in the pre final year in which we will be considering the mechanical department students of 2018 batch consisting of 140 students. 


\subsection{Threats and Opportunities}

\section{Threats and Opportunities Matrix}

\begin{tabular}{|c|c|c|}
\hline Project Objective & \multicolumn{2}{|c|}{$\begin{array}{l}\text { 1. Investigate the application of six sigma in academics } \\
\text { 2. To improve the CGPA of students for better academic opportunities. } \\
\text { 3. Increase the number of students eligible for placement activities. }\end{array}$} \\
\hline Project Sponsor & \multicolumn{2}{|l|}{ Head of Department. } \\
\hline \multirow[t]{2}{*}{ Project Stakeholder } & \multicolumn{2}{|c|}{ Students, Parents, Employers and Faculty members. } \\
\hline & Threats & Opportunities \\
\hline $\begin{array}{l}\text { Short term } \\
\text { (less than } 6 \text { months) }\end{array}$ & No major threats & Employability rate is increased \\
\hline $\begin{array}{l}\text { Long term } \\
\text { (more than } 6 \text { months) }\end{array}$ & $\begin{array}{l}\text { Wastage of money and time because } \\
\text { of the training cost. }\end{array}$ & $\begin{array}{l}\text { 1. Increase in goodwill of stake holders } \\
\text { 2. Publicity of university } \\
\text { 3. Confidence in employers } \\
\text { 4. Increase in number of admissions }\end{array}$ \\
\hline
\end{tabular}

Table 2. Threats and Opportunities Matrix

\subsection{Define Phase}

DMAIC begins with the identification and the defining of the problem statement. The goal of the 'Define' phase is to define the project goals and customer deliverable.

\subsubsection{Problem Statement}

The cumulative grade point average (CGPA) of a group of students studying mechanical engineering is taken into consideration. It is discovered that more than $65 \%$ of students have scored less than 6.5 CGPA. As a result, the number of students who did not cross the 6.5 CGPA mark are unable to attend the campus interviews, as the market demand of companies is 6.5 CGPA and above.

To improve the number of students eligible for interviews in the future, the academic performance data of the above set of students are analyzed using $6 \sigma$ tools, as we found that $6 \sigma$ methodology can be used to improve the academic performance of the students and from the literature reviews, we understand that students can be considered as raw material in educational institute's process. 


\subsubsection{Project Charter}

\begin{tabular}{|c|c|c|}
\hline \multicolumn{3}{|r|}{ Project Charter } \\
\hline \multicolumn{2}{|c|}{ Project Name } & Implementation of Six Sigma in Academia \\
\hline \multicolumn{2}{|c|}{ Description \& Goals } & Improvement of CGPA for better placement and academic opportunities \\
\hline \multicolumn{2}{|l|}{ Scope } & Meeting the requirement of the stakeholders and customers \\
\hline \multicolumn{2}{|c|}{ Business Case } & $\begin{array}{l}\text { CGPA is the most valued component of a student's life in university, } \\
\text { CGPA often works as the primary parameter when applying or being } \\
\text { considered eligible for interviews or master's programs. This paper is } \\
\text { based on the motive of increasing the student eligibility, the case study } \\
\text { is done for the Mechanical department of the } 2018 \text { batch in Presidency } \\
\text { University where there are } 140 \text { students. Out of which we have } \\
\text { considered the data of } 75 \text { students by random sampling, in this project, } \\
\text { we considered } 6.5 \text { CGPA as the minimum criteria for being eligible for } \\
\text { placement or for having a good academic record. In the process we } \\
\text { found out that only } 33.33 \% \text { of students were in the eligibility criteria } \\
\text { (6.5 CGPA and above). Therefore, the goal of the project is to provide a } \\
\text { solution by using the Six Sigma methodology to establish at least } 70 \% \\
\text { of the students eligible. }\end{array}$ \\
\hline \multirow{2}{*}{ Constraints } & Time & 4 months \\
\hline & Quality & Improvement of students CGPA \\
\hline \multicolumn{2}{|l|}{ Deliverables } & Better placements and academic opportunities \\
\hline \multicolumn{2}{|c|}{ Key Resources } & Data from Controller of Examination (COE) \\
\hline
\end{tabular}

Table 3. Project Charter

\subsubsection{SIPOC}

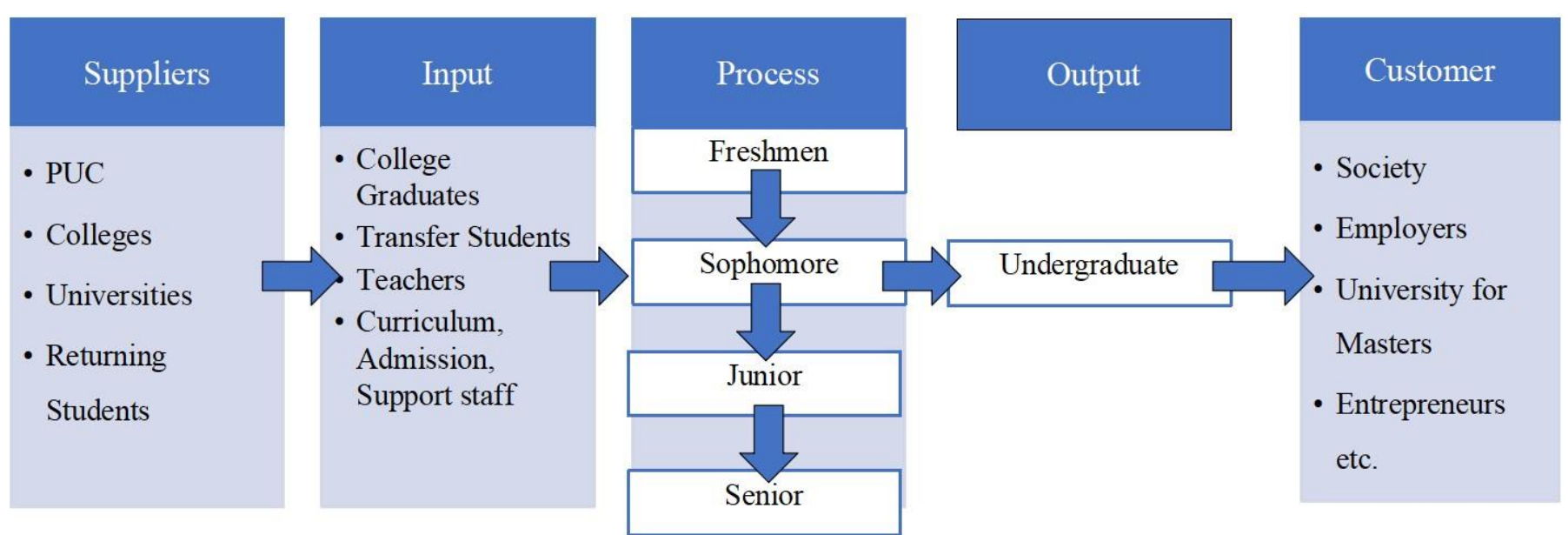

Figure 1. SIPOC process mapping of Presidency University 


\subsection{Measure Phase}

This phase is where most of numerical studies and data analysis takes place. We focus on the validation of the measurement system and gathering the root causes of the problem.

Goals of Measure Phase are:

i. Develop a data collection plan and collect relevant data.

ii. Validation of measurement system.

iii. Determinations of the process capabilities.

\subsubsection{Data Collection Plan}

Population: 2018 batch students of Mechanical Department $=140$

Sample size: students selected for project $=75$

Sampling method: Random Sampling

\begin{tabular}{|c|c|c|c|c|c|}
\hline Measure & Data Type & Operational Definition & Data Source & $\begin{array}{c}\text { Sampling } \\
\text { plan }\end{array}$ & Method \\
\hline CGPA & Discrete & $\begin{array}{c}\text { Consolidation of CGPA from } \\
\text { 1st 4 semesters of mechanical } \\
\text { department. Pre-final year } \\
\text { students using the result sheet }\end{array}$ & $\begin{array}{c}\text { Controller of } \\
\text { Examination }\end{array}$ & $\begin{array}{c}\text { Random } \\
\text { Sampling }\end{array}$ & $\begin{array}{c}\text { Result sheet which } \\
\text { contains sum of } \\
\text { continuous assessment } \\
\text { and end term marks }\end{array}$ \\
\hline
\end{tabular}

Table 4. Data collection plan

\subsubsection{Normality Test}

Normality Test is a Statistical process used to determine if a Sample or data collected fits a standard normal distribution. We use Minitab software to plot this graph.

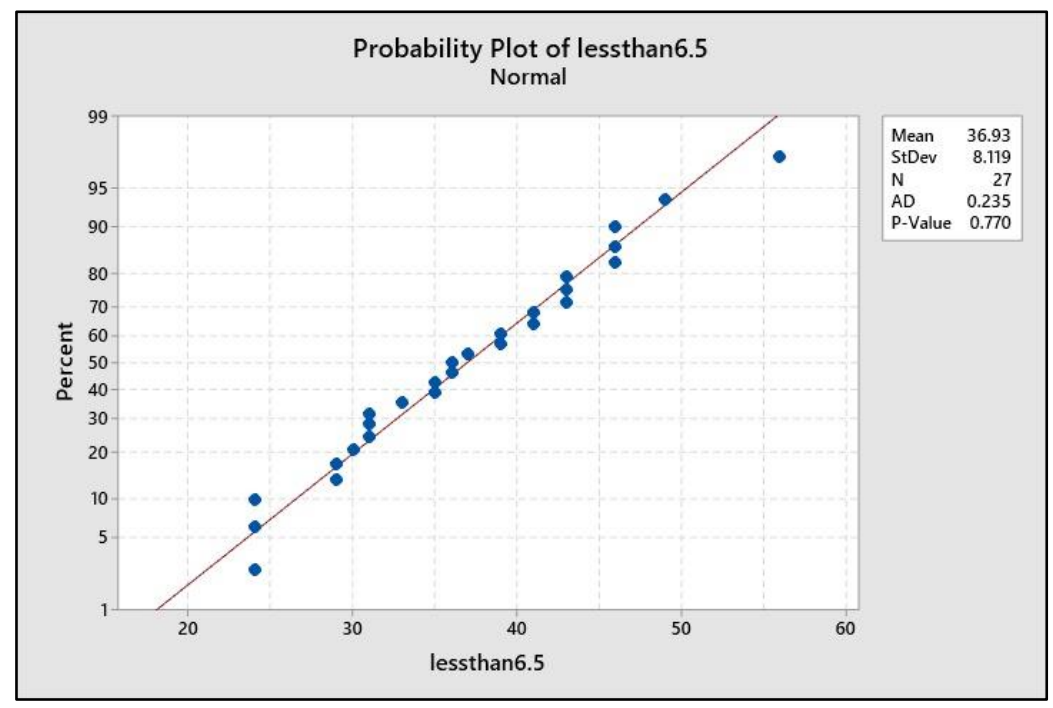

Figure 2. Normality test graph 
In the graph plotted (refer to figure 2), the blue points represent the students who scored CGPA less the 6.5 in the 27 subjects covered till the 4th semester. The top right side of figure 2, P-value table is shown. If the $\mathrm{P}-$ Value $\geq 0.05$, then the data is Normal. If the P-Value $<0.05$, then the data is not Normal. When we look at the above graph the points are in and around the straight line and the P-value is 0.770 , hence we can say that the data collected is normally distributed. And the six-sigma process can be continued.

\subsubsection{Base Lining or Sigma Calculations}

The based lining or initial sigma calculation is done to understand the current process functioning level.

Here are some of the formulae used:

\begin{tabular}{|c|c|c|}
\hline DPU & $\begin{array}{c}\text { Number of Defects Produced } \\
\text { Per Unit }\end{array}$ & Number of defects found \\
\hline DPO & $\begin{array}{c}\text { Number of Defects Produced } \\
\text { Per Opportunity }\end{array}$ & $\begin{array}{c}\text { Number of units processed (or inspected) } \\
\text { (Number of units processed (or inspected) } * \text { (Number of } \\
\text { opportunities per unit to create a defect) }\end{array}$ \\
\hline DPMO & $\begin{array}{c}\text { Number of Defects Produced } \\
\text { Per Million Opportunities }\end{array}$ & DPO $* 10,00,000$ \\
\hline
\end{tabular}

Table 5. DPMO Calculations

Total number of students $=75$

No of students who score less than $6.5=50$

Opportunity (Subjects) $=27$

Defects Per Unit $($ DPU $)=0.667$

Defects Per Opportunity $(\mathrm{DPO})=0.02469136$

Defects Per Million Opportunities $(\mathrm{DPMO})=24691.358$

Current sigma level $=3.46$

From the above calculations, the current sigma level is 3.46 which means it's at an industrial average competitive level. 


\subsection{Analysis Phase}

In this phase, critical analysis is carried out with the help of Six Sigma tools like the Fishbone diagram, also known as the Cause-and-Effect diagram, and Pareto diagram.

\subsubsection{Control Chart}

The control chart is a graph used to study how the process changes overtime. A control chart always has a central line for average, an upper line for upper control limit, and lower limit for lower control limit. The control limits are $\pm 3 \sigma$ from the central line. Attribute Charts are used for charting either-or conditions over time for either static sample size or varying sample sizes. In our project we used U- Charts is also known as the control chart for Defects per unit chart. The U- Chart is used with the varying sample size where you are counting (attribute Data) the number of defects in the Sample. There may be single defect or several different types, but $U$ chart tracks the average number of defects per unit.

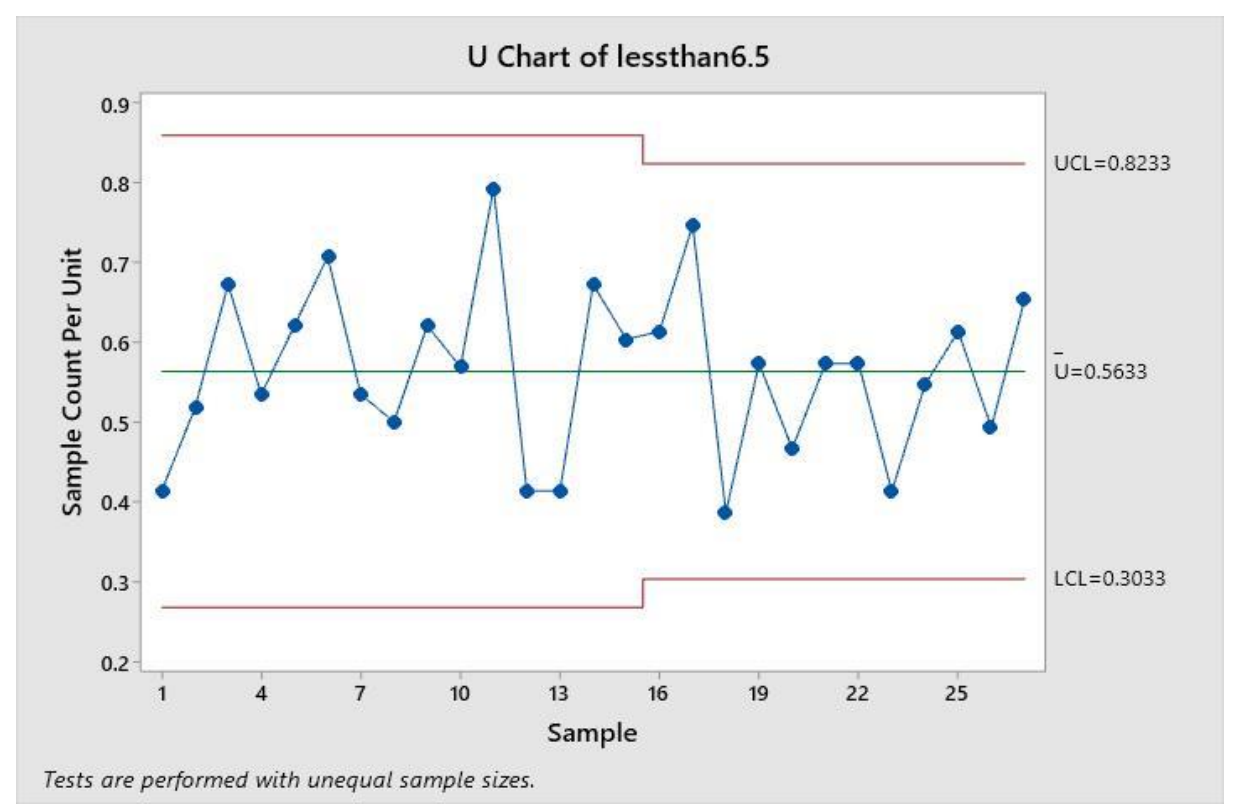

Figure 3. U-Chart

Here we have considered the 27 subjects, the sample size in each subject is either 58 or 75 as the lateral entry students only join the process in the 3rd semester, so we can see that the sample size is varying. When we have a look at the above U- Chart the points are within the control limits UCL and LCL and there are no points out of the control limits means there are no special causes variations involved and the chart indicates that the process is in control. 


\subsubsection{Cause and Effect Diagram}

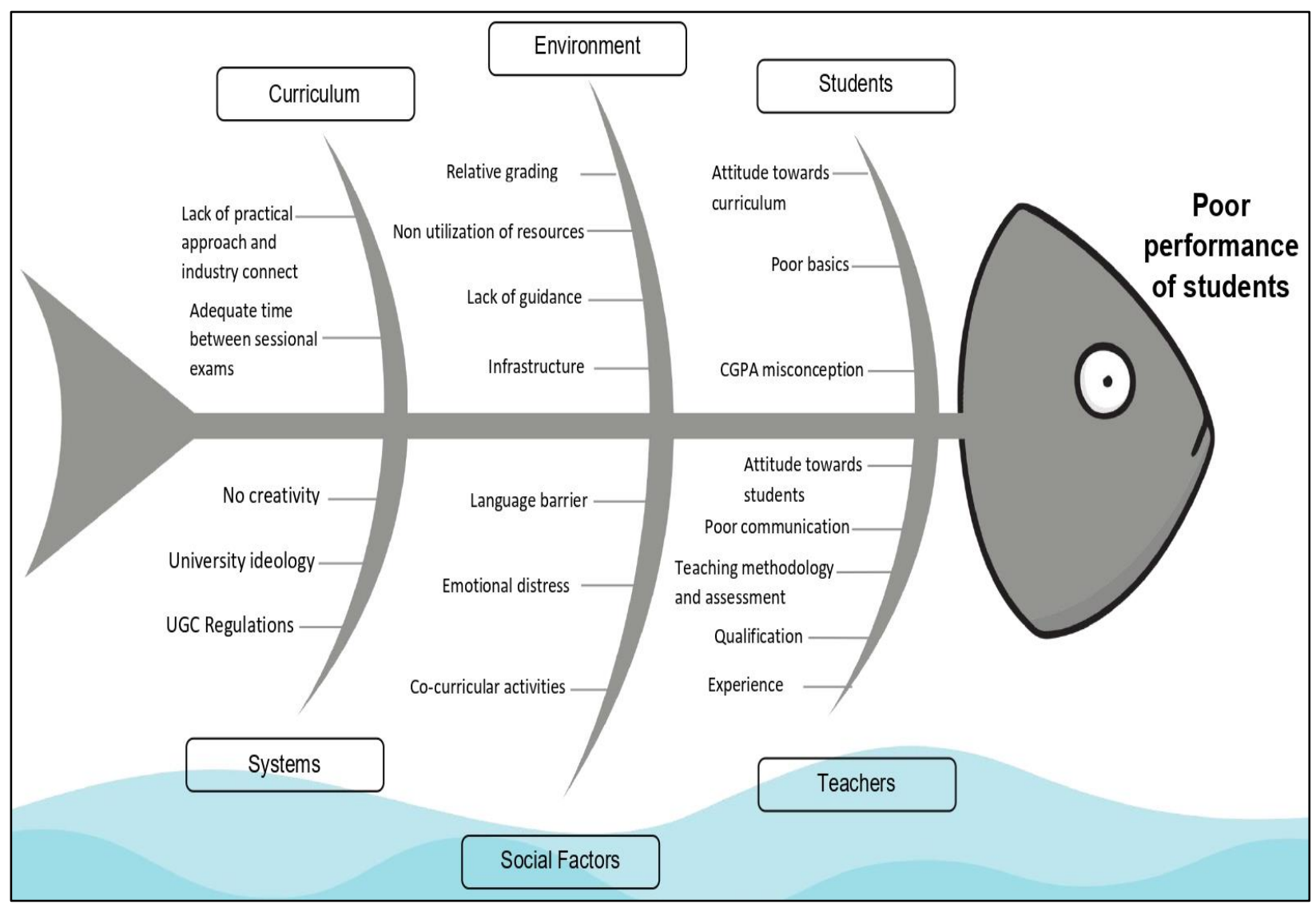

Figure 4. Fishbone diagram

\subsubsection{Pareto Diagram}

A Pareto is used to filter the many causes to vital and critical few. Pareto is a special form of Histogram, which shows the trend line and also the cumulative percentage contribution by the causes listed in the Fishbone Diagram. It works on the Pareto principle, also known as the 80/20 rule. It states that "For many events, roughly $80 \%$ of the effects come from $20 \%$ of the causes."

Now to form the Pareto chart/ diagram the causes must be quantifiable, as we can see the causes mentioned in the Fishbone cannot be quantified as they are human factors so the only possible way to quantify the causes are for us by conducting a survey.

We opted to conduct a survey among the students by asking questions based on the causes and answer them by rating the causes based on the level of importance on the scale of 1 to 5 and based on the responses the following Pareto chart was made. 


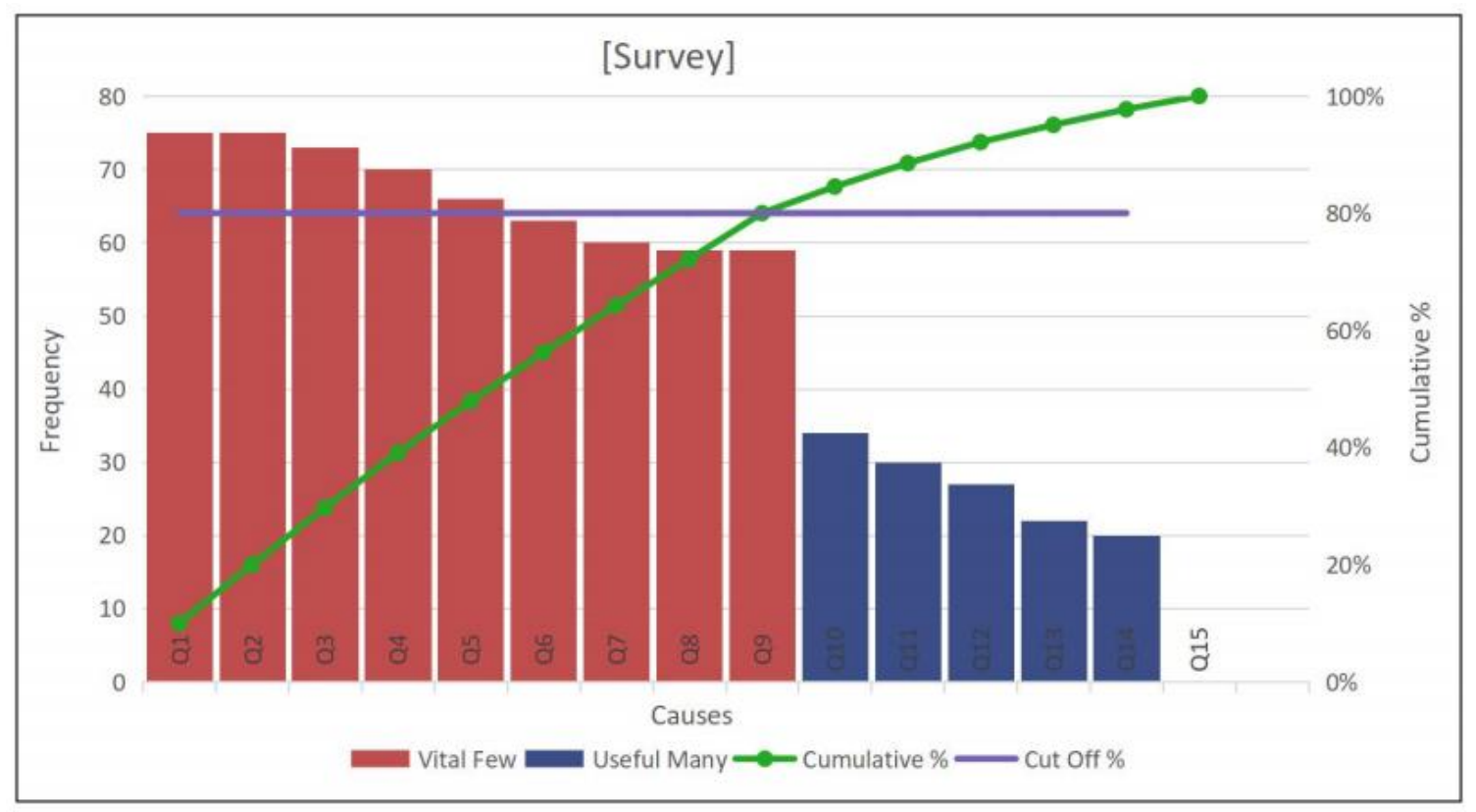

Figure 5. Pareto Chart

From the Pareto chart (Figure 5) it concluded the 9 causes are contributing to $80 \%$ of the problem and they come under Student, Social Factors, Environment, and Teacher categories of the Fishbone so if we control these causes majority of the causes of the problem are solved.

\subsection{Improve Phase}

In this phase FMEA is carried out to identify the possible failures and an implementation action plan is drafted with possible solutions for each failure identified.

\subsubsection{Failure Mode and Effect Analysis (FMEA)}

The objective here is to list out all possible failures that could occur from the shortlisted causes listed the Pareto chart/diagram. The FMEA table contains parameters such as mode of failure, effects of failure and its degree of severity (S), possible causes of failure and their probability of occurrence $(\mathrm{O})$, current prevention methods, ability to detect (D), Risk Priority Number (R), recommended actions and responsible persons. 


\begin{tabular}{|c|c|c|c|c|c|c|c|c|c|c|c|c|c|c|c|}
\hline & Potential Failure Mode & $\begin{array}{l}\text { Potential Effect on } \\
\text { Customer Because of } \\
\text { Defect }\end{array}$ & $\begin{array}{l}\text { S } \\
\text { E } \\
\text { V }\end{array}$ & Potential Causes & $\begin{array}{l}\text { o } \\
\text { c } \\
\text { c }\end{array}$ & Current Process Controls & $\begin{array}{l}D \\
E \\
T\end{array}$ & $\begin{array}{l}\mathrm{R} \\
\mathrm{P} \\
\mathrm{N}\end{array}$ & Actions Recommended & Resp.\& Target Date & Actions Taken & $\begin{array}{l}\text { S } \\
\text { E } \\
\text { V }\end{array}$ & $\begin{array}{l}0 \\
c \\
c\end{array}$ & \begin{tabular}{c|c}
$D$ & \\
E & Fu \\
$T$ & $F$
\end{tabular} & $\begin{array}{c}\text { Future } \\
\text { RPN }\end{array}$ \\
\hline Uniformity of Assessment & Different faculty evaluating & unfair grading & 8 & $\begin{array}{l}\text { Different modes(quiz, } \\
\text { presentations, etc) }\end{array}$ & 4 & Course Handouts & 2 & 64 & $\begin{array}{l}\text { no deviation from course } \\
\text { handouts }\end{array}$ & Teaching Staff & $\begin{array}{l}\text { Evaluation done on a } \\
\text { common platform }\end{array}$ & 2 & 1 & 1 & 2 \\
\hline Poor Basics & $\begin{array}{l}\text { Lack of basic concepts \& } \\
\text { understanding in Problem } \\
\text { solving skills and subjects } \\
\text { (PCM) }\end{array}$ & \begin{tabular}{|l|} 
difficulty in coping up with \\
engineering subjects
\end{tabular} & 8 & $\begin{array}{l}\text { Schooling \& studying } \\
\text { habits }\end{array}$ & 7 & Nothing & 4 & 224 & $\begin{array}{c}\text { Self study \& } \\
\text { Foundation/Bridge courses }\end{array}$ & Student \& Teaching staff & $\begin{array}{l}\text { 2hrs of bridge course } \\
\text { every weekend }\end{array}$ & 5 & 6 & 4 & 120 \\
\hline $\begin{array}{l}\text { Conduction of make up \& } \\
\text { Summer term }\end{array}$ & Not all courses are offered & carry forward of backlogs & 7 & $\begin{array}{l}\text { number of registered } \\
\text { student for a particular } \\
\text { course is less }\end{array}$ & 7 & Nothing & 1 & 49 & $\begin{array}{l}\text { offer all courses } \\
\text { irrespective of number of } \\
\text { students }\end{array}$ & Exam Dept. & $\begin{array}{l}\text { All Courses were offered } \\
\text { for make up and summer } \\
\text { term }\end{array}$ & 2 & 1 & 1 & 2 \\
\hline CGPA Misconception & $\begin{array}{l}\text { lack of knowledge about } \\
\text { grading system, CGPA, } \\
\text { importance }\end{array}$ & Low CGPA than expected & 6 & $\begin{array}{l}\text { no prior knowledge or } \\
\text { disinterest or negligence }\end{array}$ & 6 & $\begin{array}{c}\text { classroom orientation and } \\
\text { sessions at beginning of } \\
\text { each semester }\end{array}$ & 7 & 252 & $\begin{array}{l}\text { classroom interactions \& } \\
\text { faculty advisers }\end{array}$ & Student \& Teaching staff & $\begin{array}{l}\text { information dissemination } \\
\text { through all possible means }\end{array}$ & $3:$ & 4 & 5 & 60 \\
\hline Language barrier & $\begin{array}{l}\text { poor understanding and } \\
\text { interactions between } \\
\text { students and teachers }\end{array}$ & $\begin{array}{l}\text { poor understanding of } \\
\text { subject }\end{array}$ & 6 & background & 7 & $\begin{array}{c}\text { English communication and } \\
\text { PPS }\end{array}$ & 2 & 84 & practice communication & Students & communication exercises & 5 & 5 & 2 & 50 \\
\hline $\begin{array}{l}\text { Poor communication skills of } \\
\text { Faculty }\end{array}$ & $\begin{array}{c}\text { poor understanding of } \\
\text { subject by student due to } \\
\text { poor delivery skills }\end{array}$ & $\begin{array}{l}\text { loss of interest, no } \\
\text { understanding of subject }\end{array}$ & 8 & $\begin{array}{l}\text { No fluency in language, } \\
\text { background }\end{array}$ & 5 & Feedback sessions & 3 & 120 & $\begin{array}{l}\text { demo classes and on job } \\
\text { training }\end{array}$ & $\begin{array}{c}\text { Management and Teaching } \\
\text { Staff }\end{array}$ & $\begin{array}{c}\text { demo session were taken } \\
\text { for new joiners and } \\
\text { weekend training were } \\
\text { conducted for faculty }\end{array}$ & 6 & 4 & 2 & 48 \\
\hline Emotional distress & $\begin{array}{l}\text { failure in completing the } \\
\text { course. }\end{array}$ & lose of interest & 8 & $\begin{array}{l}\text { Family and Peer pressure, } \\
\text { performance anxiety }\end{array}$ & 9 & Nothing & 10 & 720 & Counselling & Management & $\begin{array}{c}\text { counselling and } \\
\text { recreational activities were } \\
\text { conducted }\end{array}$ & 6 & 7 & 8 & 336 \\
\hline lack of Co-curricular activities & no modes of stress relief & $\begin{array}{l}\text { lack of concentration in } \\
\text { class, boredom }\end{array}$ & 5 & $\begin{array}{l}\text { no facilities, negligence } \\
\text { form management }\end{array}$ & 6 & Nothing & 4 & 120 & $\begin{array}{l}\text { Provide facilities, and time } \\
\text { slots in timetable }\end{array}$ & $\begin{array}{c}\text { Management and Teaching } \\
\text { Staff }\end{array}$ & facilities were provided & 3 & 4 & 2 & 24 \\
\hline $\begin{array}{l}\text { Lack of practical approach and } \\
\text { industry connect }\end{array}$ & $\begin{array}{c}\text { students having no } \\
\text { connection to real life } \\
\text { approaches to the subject }\end{array}$ & unskilled students & 8 & $\begin{array}{l}\text { less importance given by } \\
\text { Management }\end{array}$ & 6 & IP and PP & 4 & 192 & $\begin{array}{l}\text { increase relevant industrial } \\
\text { visits }\end{array}$ & $\begin{array}{c}\text { Management and Teaching } \\
\text { Staff }\end{array}$ & \begin{tabular}{|c|} 
increase in number of \\
industrial visits and \\
technical talks by experts
\end{tabular} & 6 & 4 & 2 & 48 \\
\hline
\end{tabular}

Figure 6. FMEA

\subsubsection{Implementation Plan}

\begin{tabular}{|c|c|c|c|c|}
\hline \multicolumn{5}{|c|}{ Implementation Action Plan } \\
\hline S1.No & Precess step from FMEA & Action Item & Responsible & Due Date \\
\hline 1 & Uniformity of Assessment & No deviation from course handouts & Teaching Staff & End of semester \\
\hline 2 & Poor Basics & Self study \& Foundation/Bridge courses & Student and Teaching staff & End of semester \\
\hline 3 & Conduction of make up \& Summer term & Offer all courses irrespective of number of studnets & Exam Dept. & End of semester \\
\hline 4 & CGPA Misconception & Classroom interactions \& faculty advisers & Student and Teaching staff & End of one month \\
\hline 5 & Language barrier & Practice communication & Students & End of semester \\
\hline 6 & Poor communication skills of Faculty & Demo classes and on job training & Management and Teaching Staff & End of one month \\
\hline 7 & Emotional distress & Counselling & Management & End of semester \\
\hline 8 & Lack of Co-curricular activities & Provide facilities, and time slots in timetable & Management and Teaching Staff & End of a academic year \\
\hline 9 & Lack of practical approach and industry connect & Increase relavent industrial visits & Management and Teaching Staff & End of a academic year \\
\hline
\end{tabular}

\subsection{Control Phase}

In this phase, it is required to standardize the improvement- plan -results obtained from the Improvement Phase into Presidency University. The results of the newly standardized plan can be improved furthermore by using different six sigma tools again. Control charts are an effective way of keeping a track of performance and using the data for continuous improvement in Six Sigma methodology. 


\section{Conclusions}

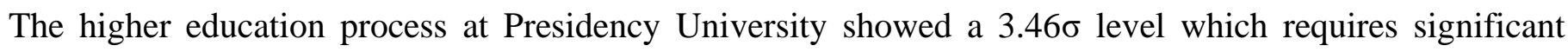
improvement to achieve a $6 \sigma$ level. The primary objective of a student is to achieve $6.5+$ CGPA to stand a chance for better academic and job opportunities, wherein failure in achieving the set CGPA, the student is considered as a defect in the $6 \sigma$ process. Some of the causes we identified for the poor performance of students are due to variations such as students coming different backgrounds, mentality, teachers and there different teaching styles, social and environmental factors, etc. After identifying the issues and defining the problems, solutions are suggested. Control charts can be used to continuously improve the education process in Presidency University and higher levels of customer (student, parents, etc.) satisfaction. The information and tools provided in this paper are an attempt to showcase how the implementation of Six Sigma is possible and successful in academia.

\section{Members of the Six Sigma Project}

The following are the core team members of the project without whom this project would not be possible:

1. Mr. Shashi Kiran G: Six Sigma Black Belt, Asst. Professor, Department of Mechanical Engineering, Presidency University, Bangalore.

2. Ms. Antara Sarode: Six Sigma Green Belt, Asst. Professor, Department of Mechanical Engineering, Presidency University, Bangalore.

3. Sohan Chandrakanth B: Six Sigma Yellow Belt, Student of Department of Mechanical Engineering, Presidency University, Bangalore.

4. Bhoomika Praveen: Student of Department of Mechanical Engineering, Presidency University, Bangalore.

5. D Pavan Kumar: Student of Department of Mechanical Engineering, Presidency University, Bangalore.

6. Gabriel Maxwell: Student of Department of Mechanical Engineering, Presidency University, Bangalore.

7. Rahul R Patil: Student of Department of Mechanical Engineering, Presidency University, Bangalore.

\section{Acknowledgment}

We wish to acknowledge and extend heartfelt gratitude to all those who have made the completion of this paper possible. Special thanks to our COE, HOD, and Professors (Department of Mechanical Engineering) for their valuable suggestions and encouragement in the formulation of this paper.

\section{References}


[1] Dr. Quamrul H. Mazumder, “Applying Six Sigma in Higher Education Quality Improvement”, Paper ID \#8594, American Society for Engineering Education, Published 2014

[2] Tannu Vats and Sujata, "Lean Six Sigma Model to Improve Student Performance”, ISSN: 0976-8491 (Online) | ISSN: 2229-4333 (Print), IJCST Vol. 6, Issue 2, April - June 2015

[3] Prabhakar Kaushik and Dinesh Khanduja, "Utilizing six sigma for improving pass percentage of students: A technical institute case study", Educational Research and Review Vol. 5 (9), pp. 471-483, September 2010

[4] C.R.S. Kumar, “ Lean Six Sigma Implementation in Engineering Institutions”, Regulating Procurement Understanding the Ends and Means of Public Procurement Regulation, 2021

[5] Milad Haerizadeh and Vijaya Sunder M, "Impacts of Lean Six Sigma on improving a higher education system: a case study", Impacts of Lean Six Sigma on improving a higher education system: a case study (2019)

[6] A. Chandra and B. K. Bhattacharya, "Application of Six Sigma Methodology in Engineering Institute", Journal of Material Science and Mechanical Engineering (JMSME) p-ISSN: 2393-9095; e-ISSN: 2393-9109; Volume 3, Issue 2; January-March, 2016 pp. 54-58

[7] Kaja Bantha Navas R, Akash R P and et al, "Six Sigma in Education - Examination Result Analysis Using Six Sigma - A Case Study”, 2016 IEEE 4th International Conference on MOOCs, Innovation and Technology in Education

[8] K.G Durga Prasad and Venkatasubbaiah Kambagowni, "Application of Six Sigma Methodology in an Engineering Educational Institution”, Int. J. Emerg. Sci., 2(2), 222-237, June 2012 ISSN: 2222-4254 @IJES 